\title{
Identification of earl millet cultivars using both microsatellites and enzymatic markers
}

\author{
R.P. Mendonça Neto, E.V.R. Von Pinho, B.L. Carvalho and G.S. Pereira \\ Laboratório de Análises de Sementes, Departamento de Agricultura, \\ Universidade Federal de Lavras, Lavras, MG, Brasil \\ Corresponding author: G.S. Pereira \\ E-mail: gabipereira87@yahoo.com.br \\ Genet. Mol. Res. 12 (1): 1-14 (2013) \\ Received May 2, 2012 \\ Accepted November 20, 2012 \\ Published January 7, 2013 \\ DOI http://dx.doi.org/10.4238/2013.January.7.1
}

\begin{abstract}
The increasing number of protected and registered cultivars and problems involving seed commercialization make distinction and identification of cultivars imperative. Millet (Pennisetum glaucum), a crop species with protected cultivars in Brazil, has been the target of seed piracy. Thus, with the objective of identifying different lots with regard to origin, we characterized six cultivars of commercialized millet of proven origin by means of the electrophoretic patterns of the isoenzymes alcohol dehydrogenase, esterase and glutamate oxaloacetate transaminase and by microsatellite markers, using primers specific for millet. The six cultivars were separated with four microsatellite loci. Based on this characterization, certification of genetic purity was undertaken for public domain commercialized seed lots. The isoenzymatic markers were also tested for stability of the patterns. Esterase patterns were altered in seeds with different physiological quality and health conditions, but this alteration did not hinder identification of the cultivars. It was observed that most of the millet seed lots commercialized in Brazil as being in public domain belong to other cultivars.
\end{abstract}

Key words: Pennisetum glaucum; Molecular markers; Seed piracy; Cultivar identification; SSR 


\section{INTRODUCTION}

Millet (Pennisetum glaucum L.) has high resistance to drought and low fertility soils, good dry matter and grain production and rapid growth (Payne, 2000). Due to these characteristics, in Brazil it is planted principally in the "Cerrado" (Tropical Savanna), in a no-till system (Durães, 2003).

With the increase of no-till planting areas in Brazil, the demand for millet seeds has grown substantially. This fact is awakening interest in genetic plant breeding companies leading to large investments in the development of new cultivars of this cereal.

The development of a superior or more productive variety demands a great deal of work, time and investment. To ensure the rights of the plant breeder over the cultivar developed, the Cultivar Protection Law (L. 9456) (Ministério da Agricultura, Pecuária e Abastecimento, MAPA) was approved in Brazil in 1997. Nevertheless, with the passing of this law, control of seed piracy has been a great challenge.

Illegal seeds are of low quality and, for that reason, have had direct effects on yield, causing losses for farmers. Therefore, certification of genetic purity of cultivars becomes an indispensable tool for ensuring a product with the genetic characteristics developed by the breeder, as well as guaranteeing protection of intellectual property (Gratapaglia and Ferreira, 1996; Vieira et al., 2009).

Morphological descriptors have been used to characterize the cultivars and guarantee their protection. However, these markers present limitations when there is narrowing of the genetic base among the cultivars, which makes differentiation among them difficult (Lanza et al., 2000; Vieira et al., 2009). Enzyme and DNA molecular markers have properties that make them extremely useful in characterization of cultivars. The SSR (simple sequence repeat) markers have the characteristic of stability and, normally, a few loci ensure complete differentiation of the genotypes of interest (Tautz and Renz, 1984; Gupta and Varshney, 2000; Morgante et al., 2002). These markers have been used in millet for the study of genetic diversity (Budak et al., 2003; Mariac et al., 2006; Kapila et al., 2007), construction of the genetic map (Qi et al., 2004), identification of cultivars (Chowdari et al., 1998), and marker assisted selection (Yadav et al., 2010).

In the present study, the identification of commercialized cultivars in millet seed lots was performed by means of enzyme and microsatellite markers. The stability of enzymatic patterns in seeds with different physiological quality and health levels was also evaluated.

\section{MATERIAL AND METHODS}

\section{Genetic material}

Seeds from the following millet cultivars were used: ADR 300, ADR 500 and ADR 7010, which are protected by the National Cultivar Protection Service (Serviço Nacional de Proteção de Cultivares) in MAPA and seeds of cultivars characterized as in the public domain: IPA Bulk 1BF from the Agronomic Institute of Pernambuco, BRS 1501 from Embrapa and $\mathrm{BN} 2$. In addition to the six cultivars cited, 23 lots of seeds collected from the national market, which were identified as belonging to cultivar BN2 of public domain, were evaluated for a total of 29 samples analyzed, in accordance with the description in Table 1. In an initial stage, the enzyme and DNA patterns of the six cultivars used as a reference were determined for later identification of the commercialized lots. 
Table 1. Relationship of the pearl millet seed samples used in cultivar identification (UFLA, Lavras, MG, 2008).

\begin{tabular}{rlcc}
\hline No. & Variety & No. & Variety \\
\hline 1 & Lot 1 & 16 & Lot 16 \\
2 & Lot 2 & 17 & Lot 17 \\
3 & Lot 3 & 18 & Lot 18 \\
4 & Lot 4 & 19 & Lot 19 \\
5 & Lot 5 & 20 & Lot 20 \\
6 & Lot 6 & 21 & Lot 21 \\
7 & Lot 7 & 22 & Lot 22 \\
8 & Lot 8 & 23 & Lot 23 \\
9 & Lot 9 & 24 & ADR 300 \\
10 & Lot 10 & 25 & ADR 500 \\
11 & Lot 11 & 26 & BN2 \\
12 & Lot 12 & 27 & IPA Bulk 1BF \\
13 & Lot 13 & 28 & BRS 1501 \\
14 & Lot 14 & 29 & ADR 7010 \\
15 & Lot 15 & & \\
\hline
\end{tabular}

\section{Extraction, electrophoresis and revealing of izoenzymes}

For extraction of the isoenzymes, 200 millet seeds from each cultivar were sampled, which were ground in the presence of polyvinylpyrrolidone (PVP), until a very fine powder was obtained. To $100 \mathrm{mg}$ powder, $250 \mu \mathrm{L} 0.2 \mathrm{M}$ extraction buffer Tris-HCI, pH 8.0, and $0.1 \%$ $\beta$-mercaptoethanol were added. The mixture was agitated and stored at $4^{\circ} \mathrm{C}$ overnight. Then, it was centrifuged at $14,000 \mathrm{rpm}$ for $30 \mathrm{~min}$ at $4^{\circ} \mathrm{C}$ and $50 \mu \mathrm{L}$ supernatant on polyacrylamide gel at $4.5 \%$ (concentrating gel) and $7.5 \%$ (separating gel) was applied. The gel/electrode buffering system used was Tris-glycine, $\mathrm{pH} 8.9$. The runs were carried out at $150 \mathrm{~V}$ for $4 \mathrm{~h}$. After the electrophoretic run, the gels were revealed and stained for the enzymatic systems: esterase (EST - EC 3.1.1.1), alcohol dehydrogenase (ADH - EC 1.1.1.1), glutamate oxaloacetate transaminase (GOT - EC 2.6.1.1), leucine aminopeptides (EC 3.4.11.1), acid phosphatase (EC 3.1.3.2), and peroxidase (EC 1.11.1.7) according to the methodology described by Alfenas et al. (1991).

\section{Evaluation of the stability of the izoenzymes}

After characterization of the cultivars, the stability of the isoenzymes was evaluated in seeds with different health and physiological quality levels in the presence of fungi in storage. Germination analyses were performed. For this purpose, 200 seeds of each cultivar were submitted to $42^{\circ} \mathrm{C}$ and $100 \%$ relative humidity for $72 \mathrm{~h}$ with the objective of deteriorating the seeds and reducing their health and physiological quality. These seeds were submitted to the blotter test for evaluation of seed health (Machado, 1998).

\section{DNA extraction}

Two hundred seeds of each cultivar were sampled and ground in the presence of liquid nitrogen and PVP, until a very fine powder was obtained. To $50 \mathrm{mg}$ seed powder, $500 \mu \mathrm{L}$ extraction buffer (0.5\% SDS, $200 \mathrm{mM}$ Tris-HCl, pH 7.5, $250 \mathrm{mM} \mathrm{NaCl}, 25 \mathrm{mM}$ EDTA, $\mathrm{pH} 8.0$ ) was added. The mixture was agitated for $5 \mathrm{~s}$ and then centrifuged at $14,000 \mathrm{rpm}$ for $5 \mathrm{~min}$ at 
$4^{\circ} \mathrm{C}$. The supernatant was collected and another centrifugation was performed at $14,000 \mathrm{rpm}$ for $5 \mathrm{~min}$ at $4^{\circ} \mathrm{C}$. After recovering the new supernatant, $400 \mu \mathrm{L}$ isopropyl alcohol at $-20^{\circ} \mathrm{C}$ was added. The mixture was lightly agitated and incubated in ice for $15 \mathrm{~min}$. After incubation, the samples were centrifuged at $14,000 \mathrm{rpm}$ for $6 \mathrm{~min}$ at $4^{\circ} \mathrm{C}$. The supernatant was discarded and $300 \mu \mathrm{L}$ ethanol at $4^{\circ} \mathrm{C}$ was added. The samples were lightly agitated and centrifuged at 14,000 rpm for 6 min at $4^{\circ} \mathrm{C}$. After centrifuging, the supernatants were discarded and the pellets were dried on the work surface at ambient temperature for $15 \mathrm{~min}$. The pellets were resuspended in $30 \mu \mathrm{L}$ ultrapure water. The samples were treated with $0.5 \mu \mathrm{L}$ RNase for $30 \mathrm{~min}$ at $30^{\circ} \mathrm{C}$. The resulting solutions were quantified by spectrophotometry in the ultraviolet region by means of NanoDrop 800 equipment (Thermo Fischer Scientific Inc., Wilmington, DE, USA). After quantification, the DNAs were diluted to the working concentration of $10 \mathrm{ng} / \mu \mathrm{L}$.

\section{Polymerase chain reactions (PCRs)}

For molecular analyses of DNA, PCRs were performed using markers based on microsatellites. Forty-three pairs of primers were tested, as described in Table 2. In the PCRs $1 \mu$ L PCR IB buffer from Phoneutria (Invitrogen Brasil Ltda., São Paulo, SP, Brazil) was used (50 mM KCl, 10 $\mathrm{mM}$ Tris-HCI, $\mathrm{pH} 8.4,0.1 \%$ Triton X-100, $2 \mathrm{mM} \mathrm{MgCl}$ ), $1.25 \mathrm{mM}$ dNTP, $6 \mu \mathrm{M}$ of each primer, 0.5 U DNA Taq polymerase from Phoneutria and $30 \mathrm{ng}$ DNA. The final volume of each reaction was $10 \mu \mathrm{L}$. The reaction program consisted of initial denaturation at $94^{\circ} \mathrm{C}$ for $4 \mathrm{~min}, 30$ cycles of $94^{\circ} \mathrm{C}$ for $20 \mathrm{~s}, 55^{\circ} \mathrm{C}$ for $20 \mathrm{~s}$ and $72^{\circ} \mathrm{C}$ for $20 \mathrm{~s}$, followed by a final elongation at $72^{\circ} \mathrm{C}$ for $5 \mathrm{~min}$.

\section{Electrophoresis}

The resulting amplicons were separated by electrophoresis on $10 \%$ acrylamide gels for $2 \mathrm{~h}$ at $120 \mathrm{~V}$. These gels consisted of $10 \%$ acrylamide:bisacrylamide (30:1), 1X TBE, $0.1 \%$ ammonium persulfate and $0.06 \%$ TEMED. The gels were immersed in a fixing solution of $10 \%$ ethanol and $0.5 \%$ acetic acid for $15 \mathrm{~min}$, followed by a $0.2 \%$ silver nitrate staining solution for $15 \mathrm{~min}$. For revelation, the gels were incubated in 3\% sodium hydroxide with $0.5 \%$ formaldehyde under agitation for $20 \mathrm{~min}$. The gels were photographed using the VilbertLoumart photo-documentation system.

\section{Evaluation of protein and enzymatic patterns}

In evaluation of the DNA and protein patterns, the presence and absence of bands in each genotype were observed, designated by 1 and 0 , respectively. A matrix of 0 and 1 was constructed and the estimate of genetic similarity (Sgij) between each pair of genotypes was calculated by Jaccard's similarity coefficient, by the following equation:

$$
\text { Sgij }=a /(a+b+c)
$$

(Equation 1)

where $a=$ presence of the band in both genotypes i and $\mathrm{j} ; b=$ presence of the band in the individual $i$ and absence in the individual $j ; c=$ absence of the band in the individual $i$ and presence in the individual $\mathrm{j}$.

Based on Jaccard's similarity coefficient, the genotypes were grouped by the unweighted pair-group method with arithmetic mean, using the NTSYS version 2.11 program (Rohlf, 1992). 
Table 2. Description of microsatellite primers of pearl millet.

\begin{tabular}{|c|c|}
\hline Primer & Sequence \\
\hline $3002 \mathrm{~F}$ & 5'-AAA GTT ACC GGG AGG GTA AAA A-3' \\
\hline $3002 \mathrm{R}$ & 5'-TCG CCT AAA AAC TGG AGG AA-3' \\
\hline $3005 \mathrm{~F}$ & 5'-CGC GGT GTT CTC ACA CAC-3' \\
\hline $3005 \mathrm{R}$ & 5'-TGT GAA TTC CGC GGG TAT AG-3' \\
\hline $3006 \mathrm{~F}$ & 5'-AAA TCG GTC GTG GTG AAG TT-3' \\
\hline $3006 \mathrm{R}$ & 5'-GAG AAT GTG GGA GAC ACA CG-3' \\
\hline $3009 \mathrm{~F}$ & 5'-CTG TAC CAT GTG CGC TGA TT-3' \\
\hline $3009 \mathrm{R}$ & 5'-GCG CAT ATA TGT GGG TGT GT-3' \\
\hline $3011 \mathrm{~F}$ & 5'-CAC GCC CTT TTT ACC TTG AC-3' \\
\hline $3011 \mathrm{R}$ & 5'-CGC GAC ACG TCC TAC ACT AA-3' \\
\hline $3013 \mathrm{~F}$ & 5'-TGT GGG AGA GAG GAG AGT CC-3' \\
\hline $3013 \mathrm{R}$ & 5'-CGC GAG ATG ATG TGT GGT-3' \\
\hline $3014 \mathrm{~F}$ & 5'-TGC TTC ACA GCC TCT CCA TA-3' \\
\hline $3014 \mathrm{R}$ & 5'-CCA CCA TGC AAC AGC AAT AA-3' \\
\hline $3016 \mathrm{~F}$ & 5'-TTG TGG CTG AAG AAG AGA TCC-3' \\
\hline $3016 \mathrm{R}$ & 5'-AAT GTG GGG AGA GAC ACA CG-3' \\
\hline $3017 \mathrm{~F}$ & 5'-CAC CAA ACA GCA TCA AGC AG-3' \\
\hline $3017 \mathrm{R}$ & 5'-AGG TAG CCG AGG AAG GTG AG-3' \\
\hline $3018 \mathrm{~F}$ & 5'-CGA TGA CAC CTG TGC GTA TT-3' \\
\hline $3018 \mathrm{R}$ & 5'-ATC GAA CTG CAC GTT AGC AA-3' \\
\hline $3019 \mathrm{~F}$ & 5'-GCG CAC CAC CTG TGT CTA T-3' \\
\hline $3019 \mathrm{R}$ & 5'-CAT GCA GAG AAA AAT CAA GCA-3' \\
\hline $3020 \mathrm{~F}$ & 5'-GTT CCA TGG AGC TGG AAG TC-3' \\
\hline $3020 \mathrm{R}$ & 5'-GCT AGA ACA GGG CCG TTA CA-3' \\
\hline $3021 \mathrm{~F}$ & 5'-GCC GAC AGG AAG ATT ACG AT-3' \\
\hline $3021 \mathrm{R}$ & 5'-AGC AAA ACG CAG AAC AAC AG-3' \\
\hline $3022 \mathrm{~F}$ & 5'-CTG GAA GTC CTT CTC GGT TG-3' \\
\hline $3022 \mathrm{R}$ & 5'-CTG CTC CGC TCT GAA TCT G-3' \\
\hline $3025 \mathrm{~F}$ & 5'-GTT GCA GAT GAG CGA TCG TA-3' \\
\hline $3025 \mathrm{R}$ & 5'-AGC GCA AAG AGT GTA ACT TGG-3' \\
\hline $3026 \mathrm{~F}$ & 5'-GTG AGG CCT CGA ACA AAC AC-3' \\
\hline $3026 \mathrm{R}$ & 5'-GCC GAC CAA GAA CTT CAT ACA-3' \\
\hline $3027 \mathrm{~F}$ & 5'-ACA CCA TCA CCG ACA ACA AA-3' \\
\hline $3027 \mathrm{R}$ & 5'-AGT GAC CTG GGG TAC AGA CG-5' \\
\hline $3028 \mathrm{~F}$ & 5'-ACG ATT CTT CGT CGT TCC AG-3' \\
\hline $3028 \mathrm{R}$ & 5'-ATA CGA TAC GCG CGA GCT AC-3' \\
\hline $3029 \mathrm{~F}$ & 5'-ACC AGC AAC AGC AGC AGA G-3' \\
\hline $3029 \mathrm{R}$ & 5'-ACA CAC TGC GAC AAG TGG AG-3' \\
\hline $3032 \mathrm{~F}$ & 5'-AGG TAG CCG AGG AAG GTG AG-3' \\
\hline $3032 \mathrm{R}$ & 5'-CAA CAG CAT CAA GCA GGA GA-3' \\
\hline $3033 \mathrm{~F}$ & 5'-GAG GGC CAG CTC TCC TAG AT-3' \\
\hline $3033 \mathrm{R}$ & 5'-CCC TAA CCA CAG AGG GAC AC-3' \\
\hline $3035 \mathrm{~F}$ & 5'-GCC AAG GAG GTC AAG ATC G-3' \\
\hline $3035 \mathrm{R}$ & 5'-ACA CGA CTC GAC TCA GAC CA-3' \\
\hline $3037 \mathrm{~F}$ & 5'-CGT CGC TGC TCT TTC TTC TT-3' \\
\hline $3037 \mathrm{R}$ & 5'-ATT TCA GAA ACG GCA ACC AA-3' \\
\hline $3038 \mathrm{~F}$ & 5'-CTC TCG GTT TGA CGG TTT GT-3' \\
\hline $3038 \mathrm{R}$ & 5'-GGG GAA AAC AAA GTT GCT CA-3' \\
\hline $3039 \mathrm{~F}$ & 5'-GGC ACG AGG GGC TAA GTA A-3' \\
\hline $3039 \mathrm{R}$ & 5'-GGA ACG CCG AGT ACA CAG AT-3' \\
\hline CTM-1 F & 5'-TCT GGG GAT TGG CTG GAA TTA CA-3' \\
\hline CTM-1 R & 5'-AAG TTG GGT AAC GCC AGG GTT TTC-3' \\
\hline CTM-2 F & 5'-GGT GAT TAA AAT CGA GGG TT-3' \\
\hline CTM-2 R & 5'-AGC AAC TTG AGC AGC GG-3' \\
\hline CTM-3 F & 5'-GTC CAT CGT CGC CGA CGA A-3' \\
\hline CTM-3 R & 5'-GGA TTT GCT AGT TGT GGG CT-3' \\
\hline CTM-8 F & 5'-GCT GCA TCG GAG ATA GGG AA-3' \\
\hline CTM-8 R & 5'-CTC AGC AAG CAC GCT GCT CT-3' \\
\hline CTM-9 F & 5'-GCC TCC TCT TGA TAC CAT ATT-3' \\
\hline CTM-9 R & 5'-TAG CCT TGG CTG CTA TAT TC-3' \\
\hline
\end{tabular}

Continued on next page 
Table 2. Continued.

\begin{tabular}{ll}
\hline Primer & Sequence \\
\hline CTM-10 F & 5'-GAG GCA AAA GTG GAA GAC AG-3' \\
CTM-10 R & 5'-TTG ATT CCC GGT TCT ATC GA-3' \\
CTM-11 F & 5'-GAC CGA TCT TCT TTG CTG TTG-3' \\
CTM-11 R & 5'-TCT ATC GTA CGT TAA CCT CA-3' \\
CTM-12 F & 5'-GTT GCA AGC AGG AGT AGA TCG A-3' \\
CTM-12 R & 5'-CGC TCT GTA GGT TGA ACT CCT T-3' \\
CTM-21 F & 5'-ATG CCT CCC ACC CCA CGT CG-3' \\
CTM-21 R & 5'-CGT CGC ACT AGC CAC AGT CA-3' \\
CTM-25 F & 5'-GCG AAG TAG AAC ACC GCG CT-3' \\
CTM-25 R & 5'-GCA CTT CCT CCT CGC CGT CA-3' \\
CTM-26 F & 5'-GCA AGT GAT CCA TGA CAT TAC GA-3' \\
CTM-26 R & 5'-ACT TGC TAG CTG CTG CTC TTG-3' \\
CTM-27 F & 5'-GTT GCA AGC AGG AGT AGA TCG A-3' \\
CTM-27 R & 5'-CGC TCT GTA GGT TGA ACT CCT T-3' \\
CTM-55 F & 5'-CGT CTT CTA CCA CGT CCT-3' \\
CTM-55 R & 5'-CAT AAT CCC ACT CAA CAA TCC-3' \\
CTM-56 F & 5'-GCG TTG TTT CGG TGA CCA C-3' \\
CTM-56 R & 5'-GCG TAT CTT TAA ATT GCC TTT GTT-3' \\
CTM-57 F & 5'-TGG TGG CAA TGC AGG CTA CAG-3' \\
CTM-57 R & 5'-AGC GAG ACG ATC GAC AGG G-3' \\
CTM-58 F & 5'-TAC GTG CTA CAA GAA TGG-3' \\
CTM-58 R & 5'-GCT GGC TAG GAC ACA A-3' \\
CTM-59 F & 5'-TCC TCG ACA TCC TCC A-3' \\
CTM-59 R R & 5'-GAC ACC TCG TAG CAC TCC-3' \\
CTM-60 F F & 5'-AAG CCC CGA TCA CAT CAA-3' \\
CTM-60 R R & 5'-AGC CGA GCC TCA TCC C-3' \\
\hline
\end{tabular}

\section{RESULTS AND DISCUSSION}

\section{Enzymatic systems}

In Figure 1 the zymograms in reference to the patterns observed for EST, ADH and GOT enzymes are presented for the cultivars ADR 300 (24), ADR 500 (25), ADR 7010 (29), BN2 (26), IPA Bulk 1BF (27), and BRS 1501 (28), in that order.

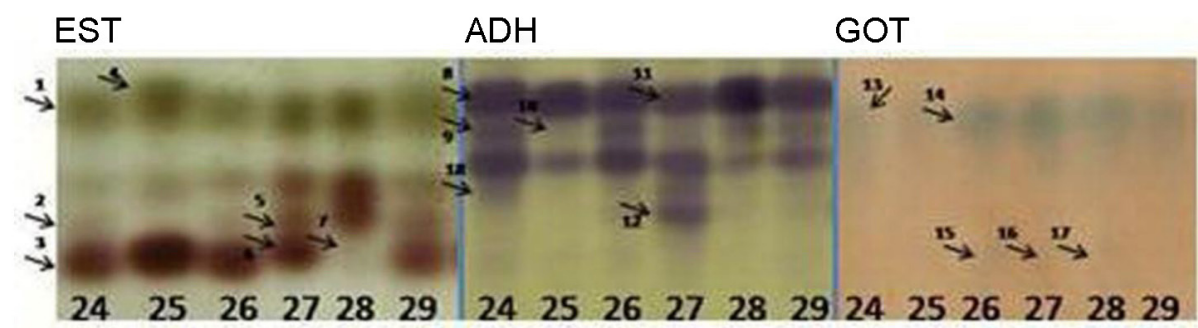

Figure 1. Zymograms of the witnesses for enzymes esterase (EST), alcohol dehydrogenase (ADH) and glutamate oxaloacetate transaminase (GOT). UFLA, Lavras, MG, 2008.

Twelve polymorphic bands were observed in all the enzymatic systems. The patterns observed in these six cultivars were used as a reference for identification of cultivars of lots commercialized as belonging to cultivar BN2, of public domain. Specific patterns were observed that differentiate the cultivars, whose bands were identified by means of numbers from 
1 to 17 . The bands of number 1 and 2 in the EST enzyme zymogram differentiated the cultivars ADR 300 from cultivar ADR 500, just as the number 9 band in the ADH enzyme zymogram. Both these cultivars are differentiated from the cultivars ADR 7010, BN2 and IPA Bulk 1BF in the GOT enzyme zymogram by the absence of bands 15,16 and 17 and by the particular pattern of band 13 on the cultivar ADR 300 (24).

The cultivar BN2 (26), was differentiated from the others principally by bands 5 and 6 of EST and 12 of ADH. The cultivar IPA Bulk 1BF (27) was differentiated from the rest by its particular pattern in reference to band number 7 in the EST system. In the GOT pattern, this was differentiated from the cultivars ADR 300, ADR 500 and BRS 1501 by the presence of band number 17. Kumar et al. (2007) by means of the EST enzyme differentiated 36 genotypes of millet.

Tostain et al. (1987) also observed polymorphism in the electrophoretic profile of the enzymes EST and ADH for millet accessions; however, the GOT enzyme pattern was monomorphic.

For the cultivars tested in this study, activities of the peroxidase enzymatic, leucine aminopeptides and acid phosphatase systems were not observed. Freitas et al. (2000), in their study, observed polymorphism in the patterns of the enzymes EST, ADH, GOT, peroxidase, leucine aminopeptides, and acid phosphatase using young leaves of millet and elephant grass accessions. The differentiated expression of enzymes in different plant tissues and organs is expected, which may justify the results observed in these studies.

The EST, ADH and GOT systems were selected for identification of the seeds commercialized as BN2, considering the results obtained in the first test.

In Figure 2 the enzymatic patterns of the enzymes EST, ADH and GOT in seeds of the 6 cultivars used as controls and those of the lots commercialized as BN2, of public domain, are presented. By means of the EST enzyme, it was observed that of the 23 lots tested, only the lots indicated as 10, 19 and 23 presented the patterns of BN2 (26) whose profiles are identified by means of the arrows indicated by the numbers 1,2,3, and 4. Evaluating the patterns of ADH, only these same three lots could be considered as from the cultivar BN2 (26), indicated by the bands of numbers 5, 6, 7, and 8 (Figure 2B).

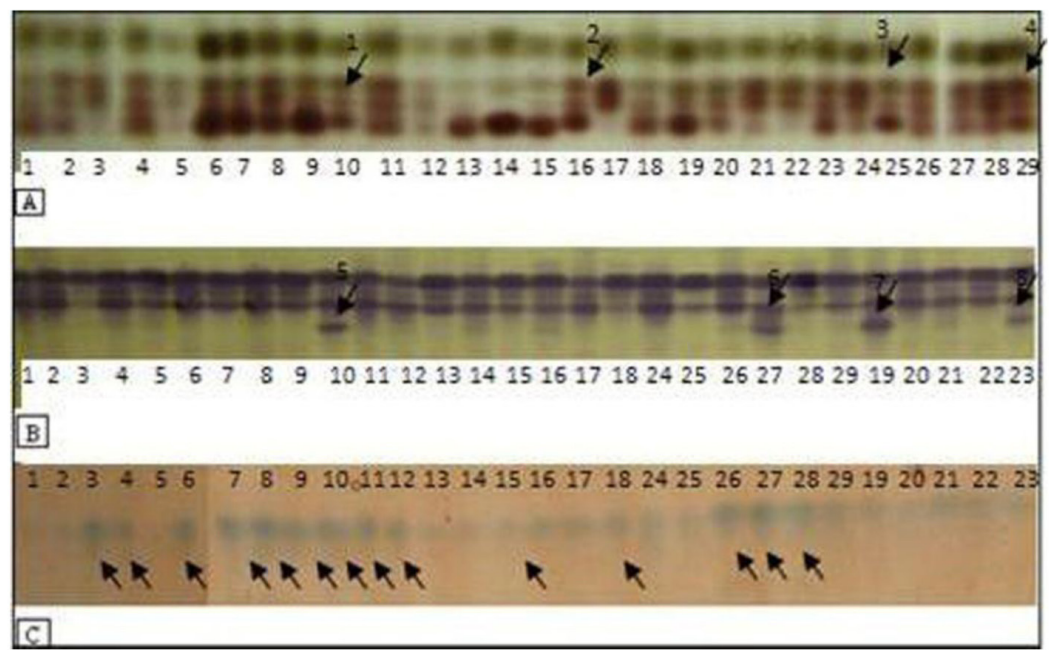

Figure 2. Electrophoretic standards of isoenzymes of pearl millet seeds A. EST. B. ADH. C. GOT. UFLA, Lavras, MG, 2008. 
By means of the GOT, similar patterns of lots $3,4,6,7,8,9,10,11,12,15,18$, and cultivars IPA Bulk (27) and ADR 7010 (29) were observed compared to those of the cultivar BN2 (25), as indicated by the arrows.

In lots $1,2,4,5,6,7,8,9,11,12,13,14,15,16,17,18,20,21,22$, and 26 , by means of the enzymes EST and ADH, different patterns were observed from those verified in the cultivar BN2, which proves seed piracy during commercialization. Mixtures of seeds from other cultivars beyond BN2 were observed.

The similarity values observed between the control cultivars and the commercialized millet lots calculated from the enzyme zymograms varied from 50 to $100 \%$. The similarity coefficient of the BN2 cultivar was 50\% in relation to the other cultivars and to the commercialized lots. Similarity of $80 \%$ was observed among the cultivars ADR 500, ADR 7010, BRS 1501 and lots 9, 13 and 17. In accordance with the coefficients, the cultivar ADR 300 presents $87 \%$ similarity to lot $14,82 \%$ to the cultivar IPA Bulk $1 \mathrm{BF}$ and $75 \%$ similarity to lots $1,2,3$, $4,5,6,7,8,10,11,12,15,16,18,19,20,21,22$, and 23 (Figure 3). The cultivar IPA Bulk 1BF presents $75 \%$ similarity with these lots and $70 \%$ with lots 9,13 and 17 .

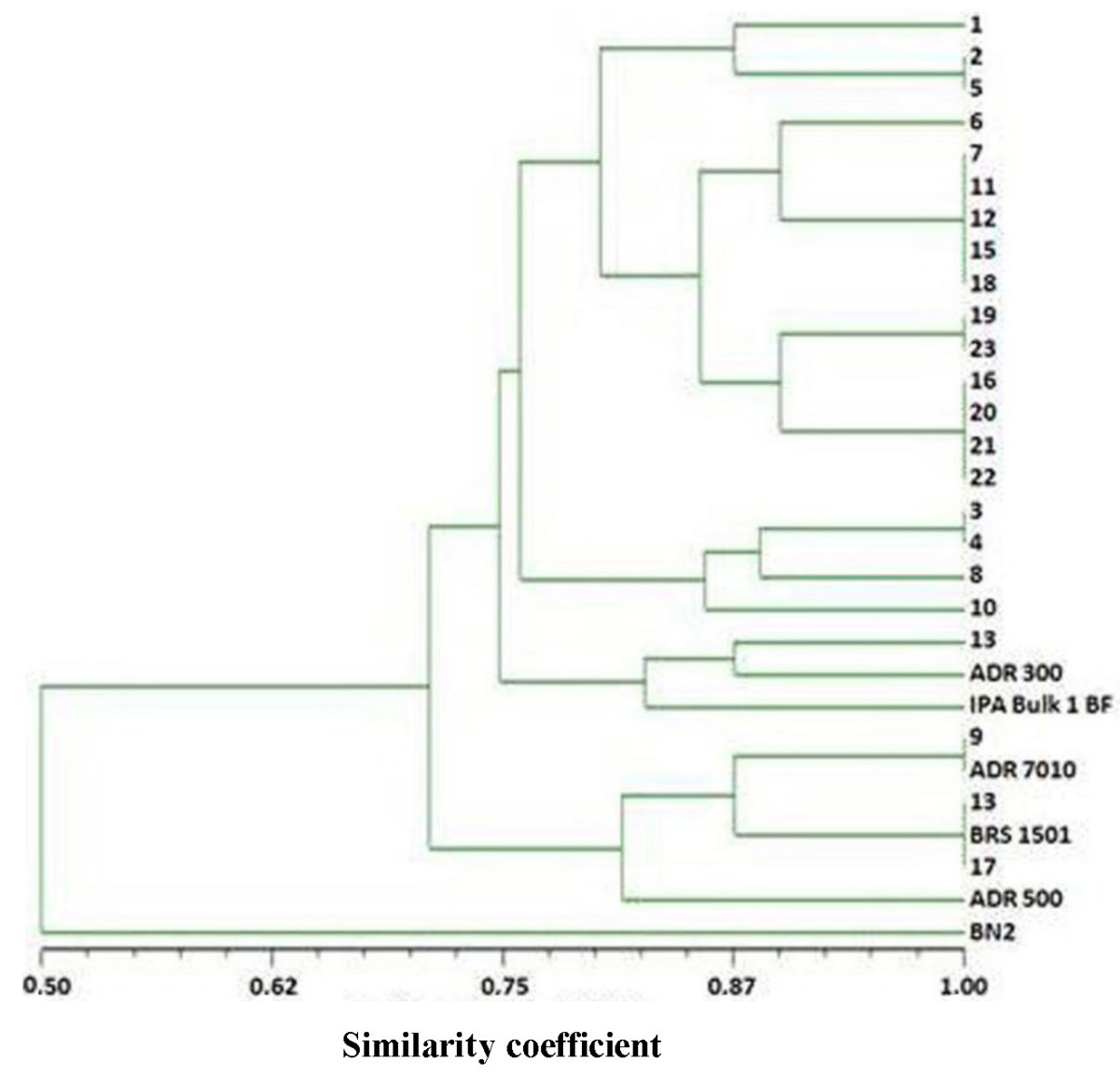

Figura 3. Dendrogram of 29 pearl millet cultivars, established in the analysis of isoenzymes of seeds. UFLA, Lavras, MG, 2008. 


\section{Stability of izoenzymes as molecular markers}

In regard to stability of the isoenzymes in relation to the presence of fungi in the seeds, alterations were observed in the patterns of EST bands for the cultivars ADR 500, IPA Bulk 1BF and BRS 1501. In Table 3, the results in germination difference of the millet cultivars submitted and not submitted to aging are presented. There was a significant reduction in the germination values of the seeds when aged.

Table 3. Germination test of aged and non-aged pearl millet seeds (UFLA, Lavras, MG, 2008).

\begin{tabular}{lcccccc}
\hline & ADR 300 & ADR 500 & ADR 7010 & BN2 & IPA Bulk 1BF & BRS 1501 \\
\hline Germination of non-aged seeds & $78.5 \%$ & $76 \%$ & $81 \%$ & $64 \%$ & $72.5 \%$ & $70 \%$ \\
Germination of aged seeds & $18 \%$ & $16 \%$ & $14.5 \%$ & $13 \%$ & $14.5 \%$ & $14 \%$ \\
\hline
\end{tabular}

In a general way, there was an increase in the incidence of pathogens Pennicilium sp, Fusarium sp, Aspergillus sp, Curvularia sp, and Dreschelera sp in the aged seeds. Alterations were not observed in patterns of GOT and ADH. Silva et al. (2000), for their part, observed changes in the electrophoretic patterns of these enzymes in corn seeds in the presence of the fungi Aspergillus flavus, Fusarium moniliforme and Penicillium spp.

In deteriorated and infected seeds, additional bands were observed in the EST patterns, as indicated by arrows (Figure 4). However, the presence of additional bands did not have an influence on the pattern used for identification of the cultivars, when the patterns presented in Figures 1 and 2 were compared, which confers stability of the patterns of these enzymes used in identification of cultivars. These results corroborate those observed by Bonow (2004) and Vieira et al. (1994) when they highlight that isoenzymes may be valuable biochemical markers in quality control of seeds. This fact is due to the bands arising from fungi being present on the gel in distinct regions of the bands that characterize the cultivars.

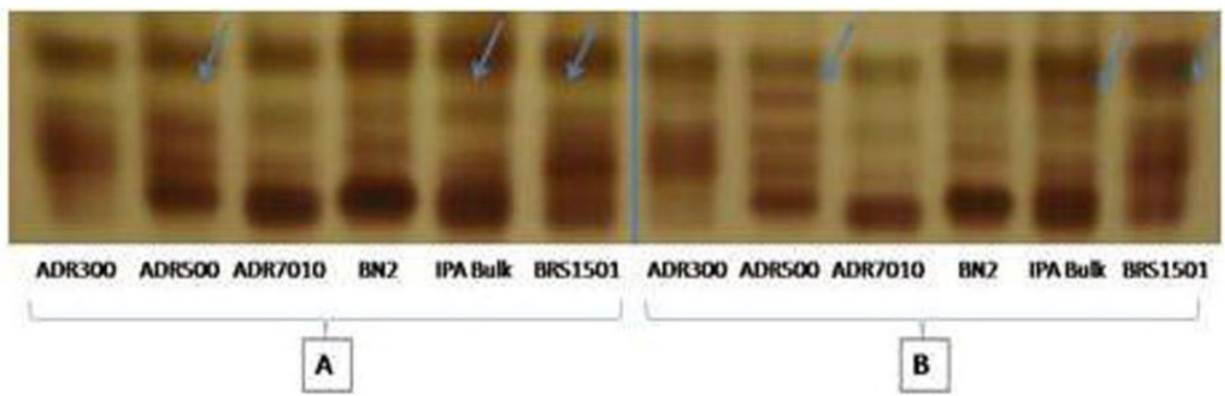

Figure 4. Electrophoretic standards of the enzyme esterase in seeds without the presence of pathogens (A) and in the presence of pathogens (B). UFLA, Lavras, MG, 2008.

\section{Evaluation of the microsatellite loci}

Of the 43 microsatellite primers evaluated, amplification of polymorphic fragments was observed in 17. The band identified by number 1 is present in the samples ADR 300 
(24) and IPA Bulk (27), differentiating them from the rest. The band identified by number 2 was observed in the cultivars BN2 (26), ADR 7010 (29), IPA Bulk (27), and ADR 300 (24), separating them from the cultivars ADR 500 (25) and BRS 1501 (29). The arrow of number 3 indicates a band present only in the cultivars IPA Bulk and ADR 300, which distinguishes these cultivars from the others analyzed. Similar patterns were observed between the cultivars IPA Bulk (27) and ADR 300 (24), using the primer 56 (Figure 5). The bands of numbers 4 and 5 indicate bands present only in these patterns. Furthermore, in the same patterns, a band was observed of number 6, present in all the cultivars, except in ADR 500 (25), BN2 (26) and ADR 7010 (29). The cultivar ADR 500 (25) presents a particular band (number 8), which separates it from all the other cultivars in question (Table 4).
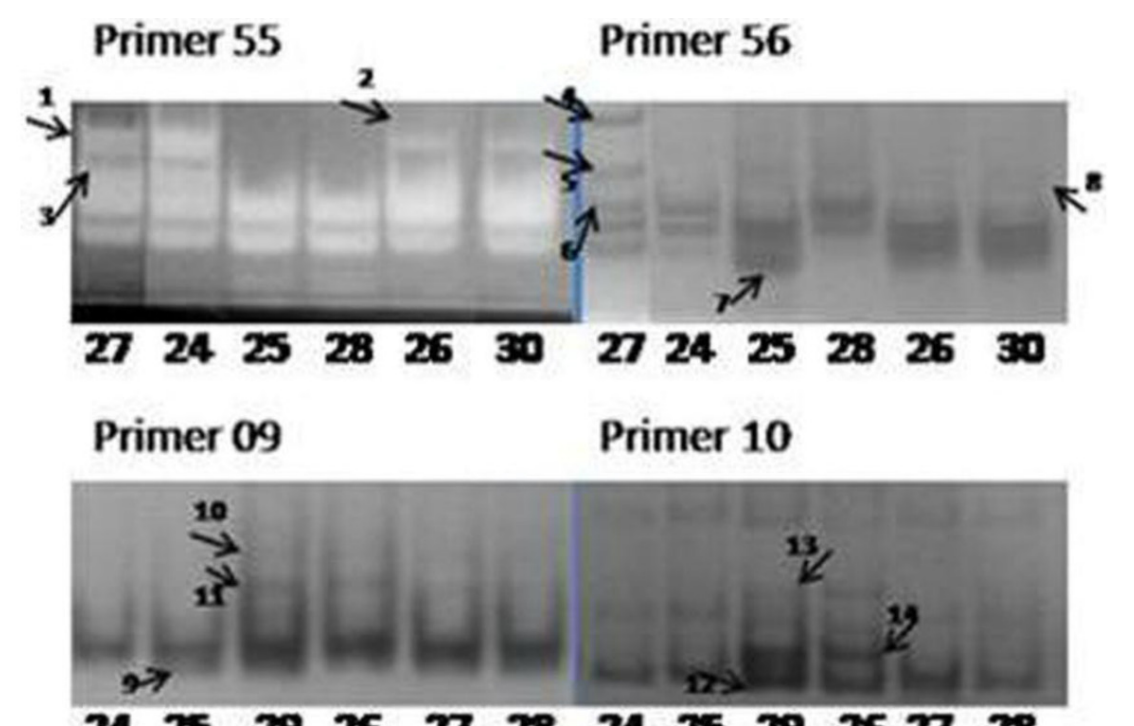

Figure 5. Observed standards of bands from the amplification of primers 55, 56, 09, and 10. UFLA, Lavras, MG, 2008.

Table 4. Health analysis of the seeds submitted and not submitted to aging (UFLA, Lavras, MG, 2008).

\begin{tabular}{lcccc}
\hline Microorganism & \multicolumn{2}{c}{ ADR 300 } & & ADR 500 \\
\cline { 2 - 4 } & Non-aged (\%) & Aged (\%) & Non-aged (\%) & Aged (\%) \\
\hline Penicillium $\mathrm{sp}$ & 23.50 & 96 & 7.50 & 86 \\
Fusarium $\mathrm{sp}$ & 14.50 & 8.50 & 0 & 1 \\
Aspergillus $\mathrm{sp}$ & 1 & 5.50 & 0.50 & 0 \\
Curvularia $\mathrm{sp}$ & 0 & 0.50 & 0 & 0 \\
Dreschelera $\mathrm{sp}$ & 3 & 0 & & 0 \\
\hline
\end{tabular}

Kapila et al. (2007) used 25 SSR primers to evaluate the genetic diversity of 421 accessions of millet cultivars from Nigeria and found a low number of polymorphic alleles.

The zymogram observed from use of the primer 09 has a band of low molecular weight (number 9) present only in the cultivars ADR 500 (25), ADR 7010 (29) and BRS 1501 
(28). In the same electrophoretic pattern, two bands are observed, identified as 10 and 11, present only in the cultivars ADR 7010, BN2 and IPA Bulk. The arrow of number 12 represents a band amplified as of primer 10, present in the cultivars ADR 7010, BN2, IPA Bulk, and BRS 1501 but absent in the cultivars ADR 300 and ADR 500. By means of the bands identified as 13 and 14, the cultivars ADR 7010 and BN2 are separated from the others.

Figure 6 shows the zymogram observed for the six control cultivars $(24,25,29,26$, 27,28 ) and in the lots commercialized as BN2, of public domain, when the primer 10 was used. With exception of the pattern observed for the cultivar ADR 7010, all the lots and cultivars under analysis present patterns different from the cultivar BN2 (Figure 6).

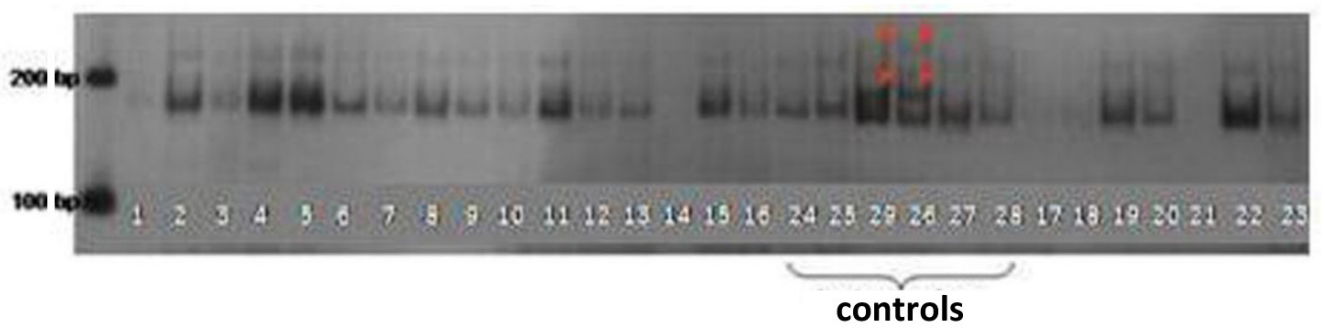

Figura 6. Electrophoretic standard of primer 10 (100-bp ladder). UFLA, Lavras, MG, 2008.

By means of the primer 55 in only 2 lots, in 11 and 20, patterns of the sample BN2 (26) (Figure 7) were observed. The zymogram of this primer presents patterns of bands of lots that belong to more than one cultivar, characterizing contamination or mixture of the seed samples, as, for example, the samples $1,2,3,4,5,6,7,8,9,10,12,13,14,15,16,17,18,19$, 21,22 , and 23.

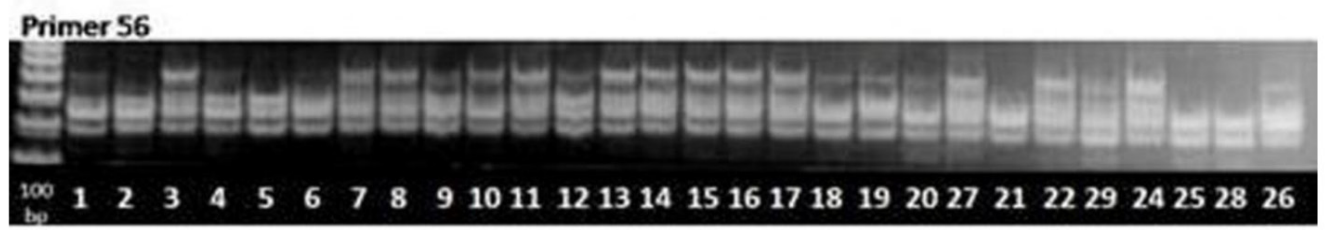

Figure 7. Standard bands from the amplification of microsatellites 55 and 56. UFLA, Lavras, MG, 2008.

By primer 56 only two lots, numbers 18 and 19, present patterns identical to those of BN2 (26). The other patterns coincide with those of the protected samples ADR 300 (24) and ADR 500 (25). The patterns of lots 1, 3, 4, 7, 8, 9, 10, 11, 12, 13, 14, 15, 16, 17, 20, 22, and 23 present the same patterns of the cultivars ADR 300 (24) and IPA Bulk 1BF (27). Lots 2, 5, 6, and 21 present patterns of the cultivars ADR 500 (25) and BRS 1501 (28) (Figure 7).

With the results obtained by means of microsatellite markers, it may be affirmed that most of the samples identified and commercialized as belonging to cultivar BN2 do not belong to the mentioned cultivar. By means of the dendrogram presented in Figure 8, similarity of only $20 \%$ was observed in relation to BN2 cultivars and the other materials used, including lots commercialized as BN2. 


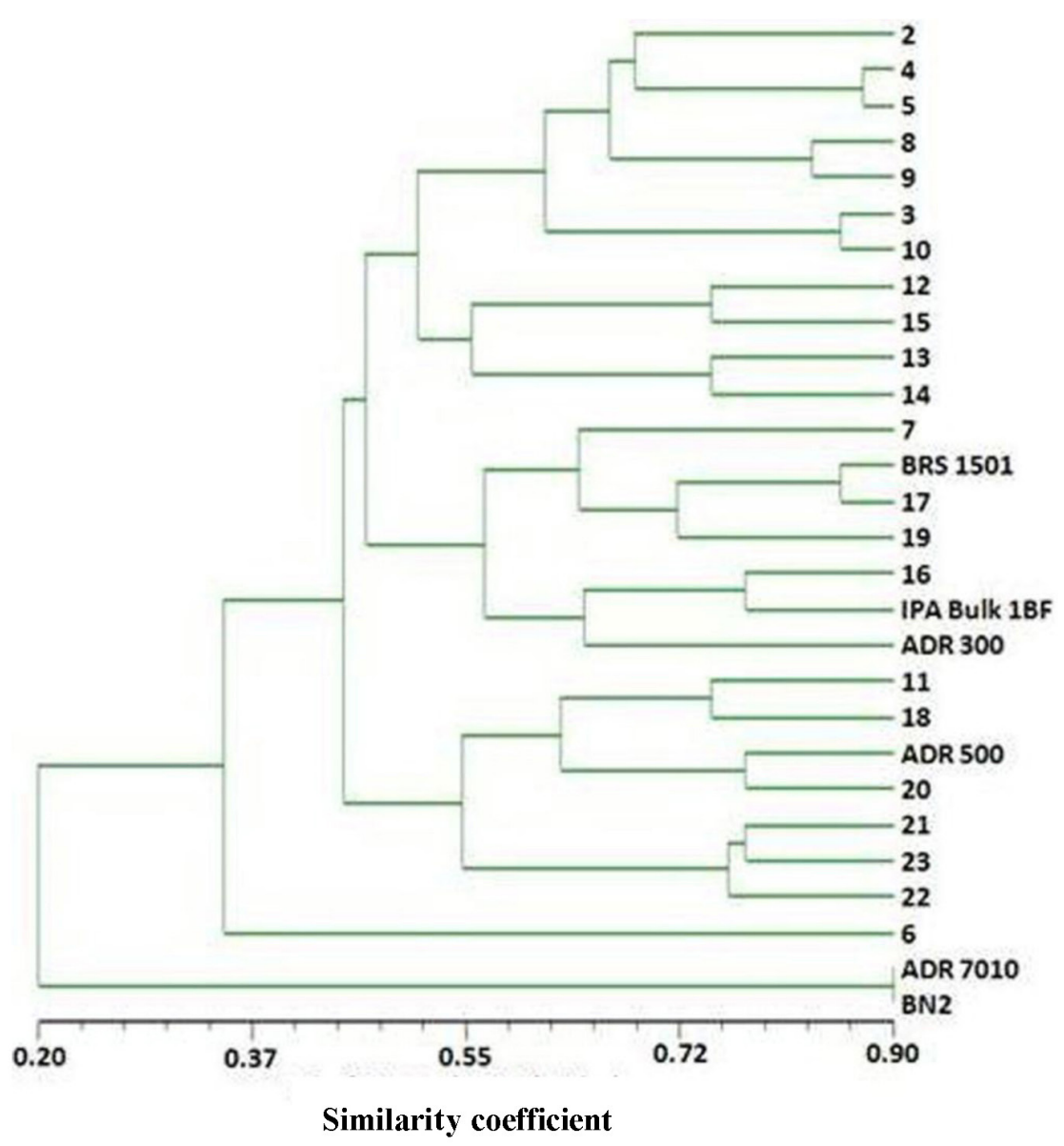

Figura 8. Coefficient of similarity dendrogram of the microsatellites. UFLA, Lavras, MG, 2008.

Among the cultivars used as controls, the greatest value of similarity $(0.90)$ was observed between the cultivars ADR 7010 and BN2. Although there are no published data regarding the genealogy of these cultivars, probably populations in common have been used in their development. These two cultivars presented a similarity index of only $20 \%$ in relation to the cultivars BRS 1501, IPA Bulk, ADR 300, and ADR 500, also used as controls in this study. For the cultivars IPA Bulk and ADR 300, the similarity index was $65 \%$. The cultivars BRS 1501, IPA Bulk and ADR 300 presented a similarity of $46 \%$. Lot 20 presented $76 \%$ similarity with the cultivar ADR 500, and this cultivar, $65 \%$ with lots 11 and 18 and $55 \%$ similarity with lots 21, 22 and 23. The cultivar ADR 300 presented $66 \%$ similarity with the cultivar IPA Bulk and lot 16 and 56\% with the cultivar BRS 1501 and lots 7, 18 and 19. Lots 2, 3, 4, 5, 8, 9, 10, $12,13,14,15$ presented $46 \%$ similarity with the cultivar ADR 300 and $43 \%$ with the cultivar ADR 500. In all the lots analyzed, differentiated patterns were observed from those observed for the control cultivars. These distinct patterns are attributed to the fact of millet being an allogamous species for which genetic contamination during seed production may occur aris- 
ing from deficient separation among fields or, moreover, due to atypical plants present in the field. These results may also be attributed to varietal contaminations due to mixtures of seeds among cultivars. These contaminations may occur during harvest, processing, transport, and storage of seeds.

\title{
CONCLUSIONS
}

By means of the patterns of the esterase, alcohol dehydrogenase and glutamate oxaloacetate transaminase enzymes of seeds, it is possible to identify the cultivars studied.

The separation of the cultivars ADR 300, ADR 500, ADR 7010, BN2, IPA Bulk 1BF, and BRS 1501 of millet was possible by means of four microsatellite loci.

Patterns of isoenzyme esterase are altered in seeds with different levels of physiological quality and seed health, but this alteration does not hinder identification of the cultivars.

Most of the millet seed lots analyzed in this study as being of public domain do not belong to the cultivar BN2.

\section{ACKNOWLEDGMENTS}

\author{
Research supported by CAPES, CNPq, Fapemig, and Sementes Adriana.
}

\section{REFERENCES}

Alfenas AC, Peters I, Brune W and Passador GC (1991). Eletroforese de Proteínas e Isoenzimas de Fungo e Essencias Florestais. Universidade Federal de Viçosa, Viçosa.

Bonow S (2004). Caracterização Morfológica, Isoenzimática e Molecular de Cultivares de Arroz de Sequeiro. Doctoral thesis, Universidade Federal de Lavras, Lavras.

Budak H, Pedraza F, Cregan PB, Baenziger PS, et al. (2003). Development and utilization of SSRs to estimate the degree of genetic relationships in a collection of pearl millet germplasm. Crop Sci. 43: 2284-2290.

Chowdari KV, Davierwala AP, Gupta VS, Ranjekar PK, et al. (1998). Genotype identification and assessment of genetic relationships in pearl millet [Pennisetum glaucum (L.) R. Br] using microsatellites and RAPDs. Theor. Appl. Genet. 97: $154-162$.

Durães FOM (2003). Fisiologia da Planta de Milheto, Circular Técnica 28. Embrapa, Milho e Sorgo (CNPMS), Sete Lagoas.

Freitas NAS, Falcão TMMA, Burity HA and Tabosa JN (2000). Caracterização e diversidade genética do capim-elefante e seus híbridos com milheto mediante padrões isoenzimáticos. Pesq. Agropec. Bras. 35: 1125-1133.

Gratapaglia D and Ferreira ME (1996). Proteção de Cultivares por Análise de DNA. Anuário Abrasem, Brasília.

Gupta PK and Varshney RK (2000). The development and use of microsatellite markers for genetic analysis and plant breeding with emphasis on bread wheat. Euphytica 113: 163-185.

Kapila RK, Plaha RS, Rai KN, Yadav OP, et al. (2007). Genetic diversity among pearl millet maintainers using microsatellite markers. Plant Breed. 127: 33-37.

Kumar MBA, Sherry RJ, Varier A and Dadlani M (2007). Suitability of seed esterases for establishing distinctness, uniformity and stability of pearl millet genotypes. Curr. Sci. 93: 951-956.

Lanza MA, Guimarães CT and Schuster I (2000). Aplicação de marcadores moleculares no melhoramento genético. Informe Agropecuário 21: 97-108.

Machado JC (1998). Patologia de Sementes. ESAL/FAEPE, MAPA (Ministério da Agricultura, Pecuária e Abastecimento). Ato no2, de 17 de janeiro de 2003. D.O.U. - Diário Oficial da Uniao; Poder Executivo, 23/01/2003. 2-3.

Mariac C, Luong V, Kapran I, Mamadou A, et al. (2006). Diversity of wild and cultivated pearl millet accessions (Pennisetum glaucum [L.] R. Br.) in Niger assessed by microsatellite markers. Theor. Appl. Genet. 114: 49-58.

Morgante M, Hanafey M and Powell W (2002). Microsatellites are preferentially associated with nonrepetitive DNA in plant genomes. Nat. Genet. 30: 194-200. 
Payne WA (2000). Optimizing crop water use in sparse stands of pearl millet. Crop Sci. 92: 808-814.

Qi X, Pittaway TS, Lindup S, Liu H, et al. (2004). An integrated genetic map and a new set of simple sequence repeat markers for pearl millet, Pennisetum glaucum. Theor. Appl. Genet. 109: 1485-1493.

Rohlf FJ (1992). Numerical Taxonomy and Multivariate Analysis System: Version 2.11. New York.

Silva EAA, Von Pinho EVR, Vieira MGGC and Carvalho MLM (2000). Alterações dos Padrões de Isoenzimas em Sementes de Milho Infectadas por Fungos. Pesq. Agropec. Bras. 35: 1725-1732.

Tautz D and Renz M (1984). Simple sequences are ubiquitous repetitive components of eukaryotic genomes. Nucleic Acids Res. 12: 4127-4138.

Tostain S, Riandey MF and Marchais L (1987). Enzyme diversity in pearl millet (Pennisetum glaucum). Theor. Appl. Genet. 74: 188-193.

Vieira AR, Vieira MGGC, Carvalho VD and Fraga AC (1994). Efeitos de tratamentos pré-germinativos na superação da dormência de sementes dearroz e na atividade enzimática da peroxidase. Pesq. Agropec. Bras. 29: 535-542.

Vieira ESN, Von Pinho EVR, Silva PA and Vieira MGGC (2009). Caracterização de cultivares de soja por meio de descritores morfológicos e marcadores bioquímicos de proteínas e isoenzimas. Rev. Bras. Sementes 31: 53-63.

Yadav RS, Sehgal D and Vadez V (2010). Using genetic mapping and genomics approaches in understanding and improving drought tolerance in pearl millet. J. Exp. Bot. 1: 12. 